\title{
Approaches to Teaching Building Materials and Technologies for Energy-Efficient Sustainable Construction
}

\author{
Nataliya Lushnikova \\ Department of Architecture and Environmental Design, \\ National University of Water and Environmental Engineering, Rivne, Ukraine, \\ e-mail:n.v.lushnikova@nuwm.edu.ua
}

\begin{abstract}
There are highlighted the peculiarities of teaching subjects "Building Materials in Energy-efficient Construction" and "Technologies in Sustainable Construction" developed in English within the scope of Civil Engineering Master Studies curricula „Building ecological Europe”. Basic objectives, teaching methods, content of the lectures and course project, and course results are considered.
\end{abstract}

Keywords: building material, energy efficiency, sustainability, construction technology, life-cycle assessment.

\section{Introduction}

Energy efficiency and comfort are two new critical expectations of owners of modern buildings [1]. At the same time $42 \%$ of the total annual impact of buildings attributes to high-energy use and $30 \%$ to materials use in USA and other developed countries [2]. Energy efficiency is a key aspect of sustainability of a building.

The purpose of the article is the revealing the main approaches and issues of the subjects "Building Materials in Energy-efficient Construction" and "Technologies in Sustainable Construction", developed within the Civil Engineering Master Studies curricula „Building ecological Europe” at the Faculty of Civil Engineering and Architecture in Lublin University of Technology. The scope of the article covers basic objectives, teaching methods, content of the lectures and course results.

Both of the subjects have lectures on different types, properties of energy-efficient building materials and their application in technologies of sustainable construction. Course project permits to accumulate and analyze the data given in lectures to make practical solution for construction assemblies of a building. In the end of the subjects, there is scheduled exam on lectures and assessment of course project. Total number of class hours is 60 , among them lectures take 30 hours, course project takes 30 hours.

There are similar subjects in the Universities of Technologies in Poland for Civil Engineering students of the second stage of studying, most of them are taught in Polish. There are for instance, "Materials in energy-saving construction" in Opole University of Technology [3] or "Ecological technologies in building industry" in Rzeszów University of Technology [4]. There are specializations at Master level on Sustainable Construction (Warsaw University of Technology) [5], Energy-efficient Construction (West Pomeranian University of Technology Szczecin) [6], Energy Saving Construction (University of 
Warmia and Mazury in Olsztyn) [7] and some other universities of Poland as well as in other countries of EU. For instance, there is one-year full-time course on Sustainable Building Technology (MSc) in University of Nottingham (UK) [8] or two-year Energyefficient and Environmental Building Design - Master's Program in Lund University (Sweden) [9]. The International Erasmus + programs on energy-efficient and sustainable construction due to involving students from different countries, permit to give the idea about the most important issues of modern construction and suggest rational decisions for the problems common for different countries and regions.

\section{Subject "Building Materials in Energy-efficient Construction"}

\subsection{General information}

The main objectives of this subject are as follows:

- gaining knowledge of the energy efficiency criteria for building materials;

- obtaining knowledge of the types and properties of building materials for energyefficient construction;

- acquiring the ability to select rationally building materials for energy-efficient construction;

- understanding possible uses of different methods and tools for estimating the energy efficiency of buildings.

The prerequisites to study the subject are the knowledge of physics and chemistry of building materials and basic knowledge of the methods applied in selecting building materials for energy-saving construction.

\subsection{Main issues}

At the start of the lecturing there are set terms applied during the studying. Term 'energy efficiency' to wide extent is applied to building materials and it means saving energy resources at all the stages of materials life: from extraction of raw to its disposal, in other words during their life-cycle. This means reduction of embodied energy (the total energy required to produce building material), saving operation energy during material's performance and possibility of alternative wastes disposal (reusability, recyclability or biodegradabity of building materials). During the performance as the longest stage of building material life cycle it is expected that application of the building material will lead to improvement of thermal and moisture comfort in the building [1] and to reduction of financial expenses for the construction and performance. In terms of energy-efficient sustainable construction there are expected ecological effects as the reduction of carbon dioxide emissions and global greenhouse gases emissions.

Basic criteria of suitableness of building material to energy-efficient construction are physical (mostly thermal) parameters such as specific heat capacity, thermal conductivity, and calculated, based on previous thermal resistance, thermal transmittance, thermal diffusivity and effusivity. The most important energy parameter estimated for a building is annual energy consumption. According to data of Polish Association for Sustainable Development for energy-efficient building (Energy class label B) it varies between 45 and $80 \mathrm{kWh} / \mathrm{m}^{2} \mathrm{y}$; according to the data of BER (Building Energy Rating) International Energy agency (2010) it must be up to 75 (for B1), up to 100 (for B2), up to 125 (B3) $\mathrm{kWh} / \mathrm{m}^{2} \mathrm{y}$.

To enclose different types of such materials including novel composite and advanced materials there is proposed classification according their function based on accumulated data (Tab. 1). 
Table 1. Types of building materials for energy-efficient buildings (accumulated data according to $[1,10]$ )

\begin{tabular}{|c|c|c|c|c|}
\hline Function & Materials & Application & Requirements & Reason for using \\
\hline $\begin{array}{l}\text { Thermal } \\
\text { insulation (static } \\
\text { and dynamic) }\end{array}$ & $\begin{array}{l}\text { Porous materials } \\
\text { with dominance of } \\
\text { closed porosity, } \\
\text { fibrous materials, } \\
\text { insulation value of } \\
\text { still air is used } \\
\text { (static) } \\
\text { Advanced and } \\
\text { smart materials }\end{array}$ & $\begin{array}{l}\text { Layers of outer } \\
\text { walls, roofs, floors }\end{array}$ & $\begin{array}{l}\text { High thermal } \\
\text { insulation properties; } \\
\text { stability and long } \\
\text { lifespan; fire } \\
\text { resistance; } \\
\text { lack of odor; low } \\
\text { chemical activity; } \\
\text { ability to cope with } \\
\text { moisture }\end{array}$ & $\begin{array}{l}\text { Reducing the flow of } \\
\text { heat through the exterior } \\
\text { surfaces of the building; } \\
\text { reduction of energy } \\
\text { consumption for heating } \\
\text { and air-conditioning }\end{array}$ \\
\hline $\begin{array}{l}\text { Thermal } \\
\text { stabilization } \\
\text { (thermal energy } \\
\text { storage) }\end{array}$ & $\begin{array}{l}\text { Materials with } \\
\text { high thermal } \\
\text { density, phase } \\
\text { changing materials }\end{array}$ & $\begin{array}{l}\text { Envelope structures, } \\
\text { energy equipment }\end{array}$ & $\begin{array}{l}\text { High thermal density, } \\
\text { low thermal } \\
\text { diffusivity }\end{array}$ & $\begin{array}{l}\text { Conserving energy, for } \\
\text { later use; minimization } \\
\text { temperature fluctuations; } \\
\text { maximization output } \\
\text { from renewable energy } \\
\text { supply source }\end{array}$ \\
\hline Heat reflection & Metal foils & $\begin{array}{l}\text { Layers on envelopes } \\
\text { surface }\end{array}$ & $\begin{array}{l}\text { High radiant heat } \\
\text { reflection }\end{array}$ & $\begin{array}{l}\text { Elimination transfer of } \\
\text { radiant heat }\end{array}$ \\
\hline Multi-function & $\begin{array}{l}\text { Multilayered } \\
\text { (sandwich) with } \\
\text { porous or fibrous } \\
\text { layer glazing } \\
\text { masonry, panels) }\end{array}$ & $\begin{array}{l}\text { Serve both for } \\
\text { thermal regulating } \\
\text { and structural, } \\
\text { finishing, } \\
\text { translucency etc. }\end{array}$ & $\begin{array}{l}\text { High thermal } \\
\text { insulation properties; } \\
\text { stability and long } \\
\text { lifespan }\end{array}$ & $\begin{array}{l}\text { Combination in one } \\
\text { material different } \\
\text { functions, reduction of } \\
\text { energy and resources for } \\
\text { installation process }\end{array}$ \\
\hline
\end{tabular}

Properties of thermal insulating building materials are studied according to matrix (Tab. 2).

Table 2. Matrix of studied properties for thermal insulating building materials

\begin{tabular}{lllll}
\hline $\begin{array}{l}\text { Physical and } \\
\text { mechanical } \\
\text { properties }\end{array}$ & Density & $\begin{array}{l}\text { Water vapor diffusion } \\
\text { resistance factor }\end{array}$ & Tensile strength & $\begin{array}{l}\text { Compressive } \\
\text { strength }\end{array}$ \\
\hline $\begin{array}{l}\text { Thermal } \\
\text { and fire } \\
\text { properties }\end{array}$ & $\begin{array}{l}\text { Thermal } \\
\text { conductivity }\end{array}$ & $\begin{array}{l}\text { Specific heat } \\
\text { capacity }\end{array}$ & $\begin{array}{l}\text { Maximum service } \\
\text { temperature }\end{array}$ & Reaction to fire \\
\hline $\begin{array}{l}\text { Ecological } \\
\text { properties }\end{array}$ & Calorific value & Primary energy input & $\begin{array}{l}\text { Global Warming } \\
\text { Potential (GWP) }\end{array}$ & $\begin{array}{l}\text { Acidification } \\
\text { Potential (AP) }\end{array}$ \\
\hline & Boards & Batts & Loose fill & Caulking \\
\hline $\begin{array}{l}\text { Form } \\
\text { of supply }\end{array}$ & Solid wall & Floor & & \\
\hline
\end{tabular}


The most common thermal insulating materials can be compared by their thickness of insulation layer required to achieve U-value $0.2 \mathrm{~W} /\left(\mathrm{m}^{2} \mathrm{~K}\right)$ (see Fig. 1) and embodied energy (from cradle to gate) (see Fig. 2). It permits to compare energy efficiency of the thermal insulating materials instantly.

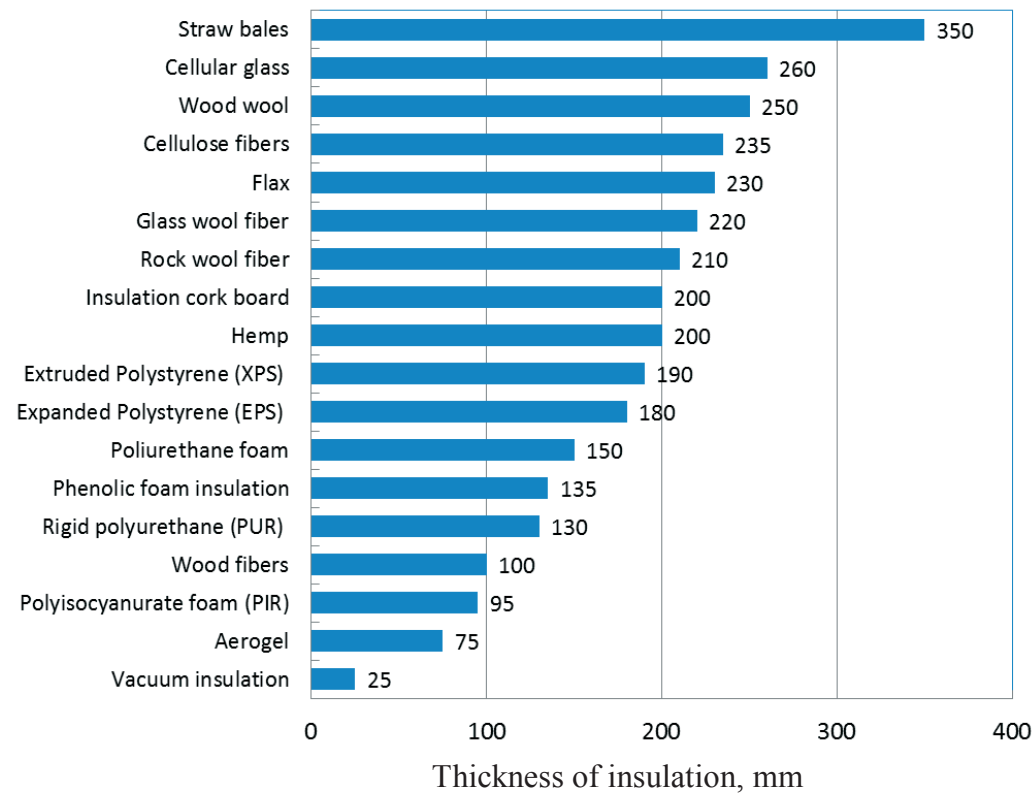

Fig. 1. Thickness of insulation layer required to achieve U-value $0.2 \mathrm{~W} /(\mathrm{m} 2 \mathrm{~K})$, based on accumulated data

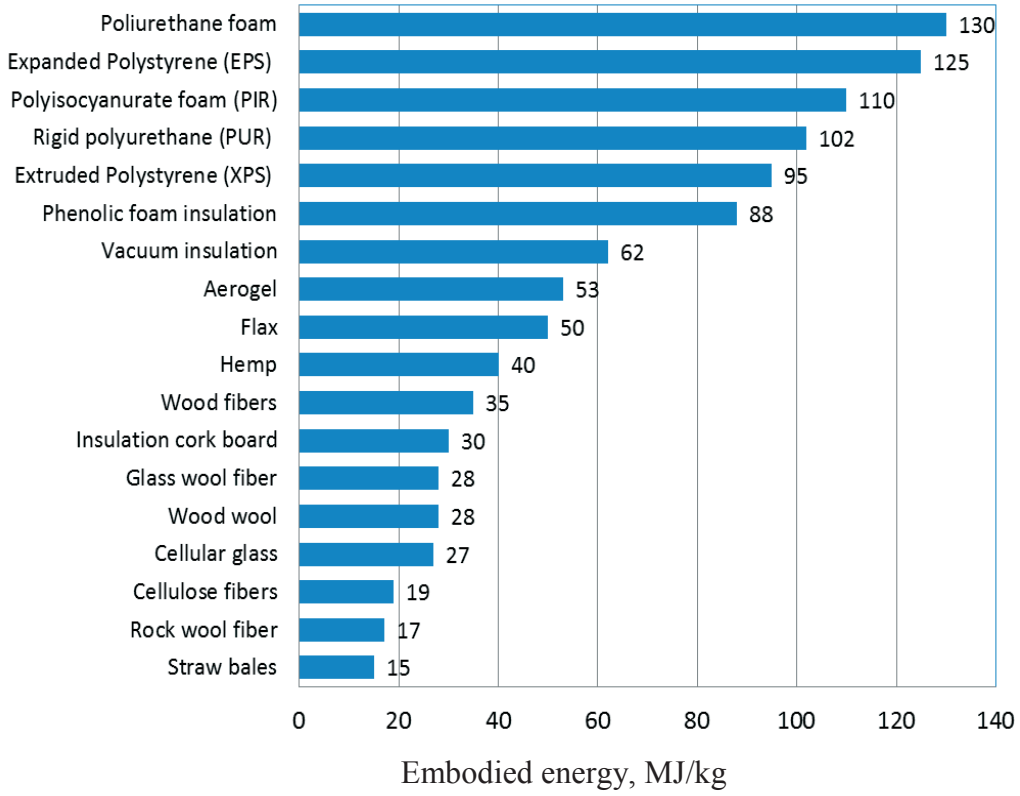

Fig. 2. Embodied energy (from cradle to gate) of insulation materials, based on accumulated data 
There are considered widespread inorganic and organic natural and synthetic heatinsulating materials, as well as advanced heat-insulating materials (aerogel products, vacuuminsulated panels). There are discussed advanced materials and techniques for energy-efficient buildings such as dynamic and hybrid insulation. In the case of dynamic one it is possible to achieve the dual function of reducing the heat loss through walls and/or roof, whilst at the same time supplying pre-warmed air to indoor spaces (Fig. 3). Reflective insulation elements can be applied along with ordinary thermal insulating materials in hybrid systems (Fig. 4).

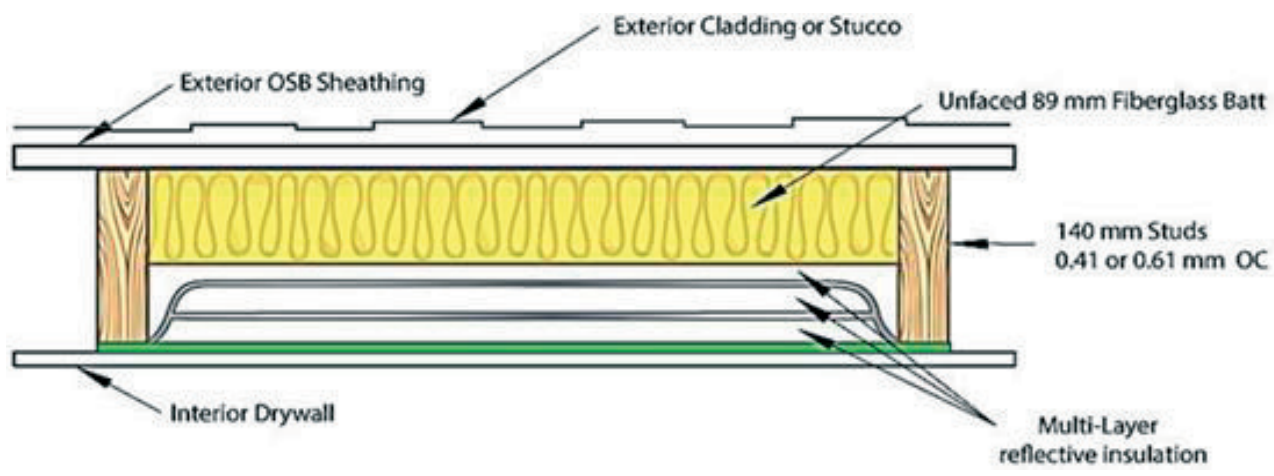

Fig. 3. Principle scheme of dynamic insulation, adapted from [11]

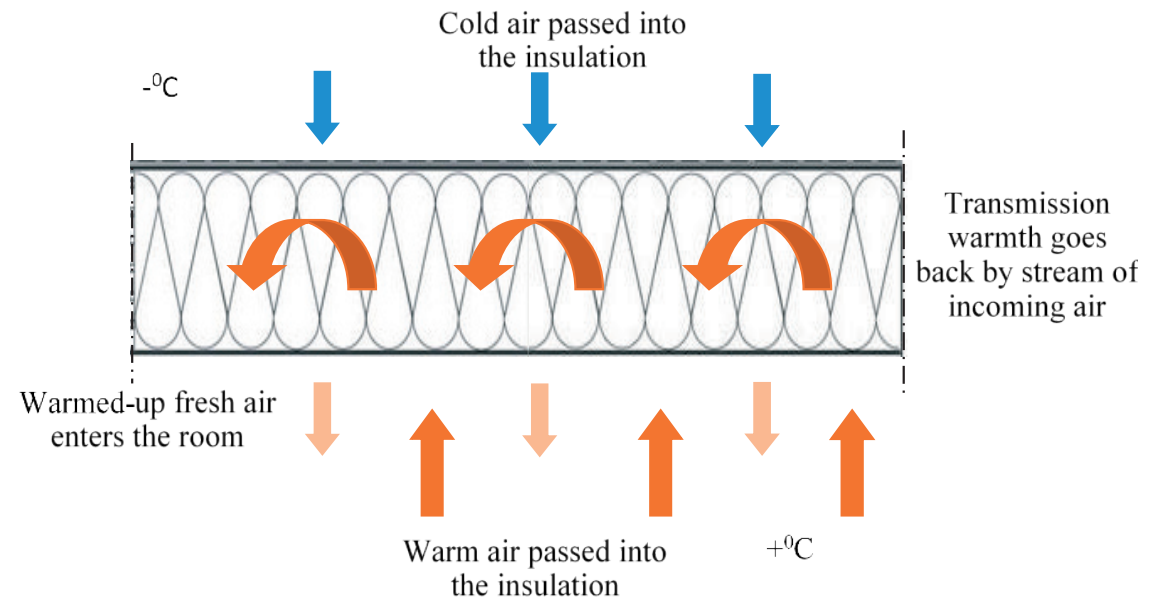

Fig. 4. Hybrid insulation: fibreglass and reflective assembly in a wood framed wall [10]

There is also paid attention to multifunctional materials, which have both insulating and structural functions in the buildings. There are prefabricated building units like insulated blocks, metal-faced insulating sandwich panels, energy-saving smart glass systems etc. 


\section{Subject "Technologies in Sustainable Construction"}

Energy efficiency is an integral part of sustainability, which is a complex characteristic attributed to building materials as well as to buildings. Under 'sustainable construction' rather large amount of different aspects is meant. El Khouli et al. [13] suggests to consider efficient use of material and energy resources, which pose no risk to health as main criteria. According to M. Pulaski [14] sustainable material must be durable, reusable or recyclable, biodegradable, locally manufactured.

\subsection{General information}

The main objectives of this subject are

- gaining knowledge of the key aspects of sustainable construction;

- obtaining knowledge of the basic technologies used in sustainable construction;

- acquiring the ability to rational selection energy-efficient ecological building materials for sustainable construction;

- understanding possible uses of different methods and tools for estimating the influence of buildings on the environment.

The prerequisites to study the subject are basic knowledge of building physic and knowledge of properties of building materials and the methods applied in sustainable construction.

\subsection{Main issues}

Main issues of the lectures under consideration are basic technologies applied in sustainable construction; natural local raw materials and traditional technologies; recycled and reused products in sustainable construction; advanced and smart materials and technologies in sustainable construction. At first students will be acquainted with priorities in selection of materials and technologies for sustainable construction at the phases of life cycle of a building (Tab. 3).

From the point of meeting these criteria, the main discussed technologies are considered (Tab. 4). Much attention is paid to the technologies of sustainable construction based on application natural local materials (earthwork techniques, timber and straw products), composite materials (hempcrete). Application of reused products of high durability (like steel structures and reinforced concrete elements), products with recycled content (for instance masonry units) is also considered.

There are discussed cellular clay block systems as lightweight energy-effective construction techniques. The smart technologies of smart glazing and photovoltaic power systems are also under consideration. 
Table 3. Priority in selection of materials and technologies for sustainable construction in terms life cycle phases (adapted according to [12])

\begin{tabular}{|c|c|c|}
\hline $\begin{array}{l}\text { Phase } \\
\text { of life-cycle }\end{array}$ & Criteria & Priority in selection \\
\hline \multirow{6}{*}{ Raw materials } & Origin & Natural origin/ Recycled content \\
\hline & Renewable resources & Raw materials from (quickly) renewable resources \\
\hline & Content & No harmful substances \\
\hline & Availability and spread & Common availability and wide-spread resources \\
\hline & Environmental impact & $\begin{array}{l}\text { Activities on raw materials make minimum negative } \\
\text { environmental impact and are safe for human health }\end{array}$ \\
\hline & Energy consumption & $\begin{array}{l}\text { Minimum in energy consumption/ Energy from } \\
\text { renewable resources }\end{array}$ \\
\hline \multirow[t]{2}{*}{ Production } & Energy consumption & $\begin{array}{l}\text { Minimum in energy consumption/ Energy from } \\
\text { renewable resources }\end{array}$ \\
\hline & Water consumption & Low water consumption \\
\hline \multirow{4}{*}{ Production } & Solid waste production & $\begin{array}{l}\text { Minimum solid and liquid waste generation/ Wastes with } \\
\text { utility value }\end{array}$ \\
\hline & Liquids waste production & Possibility of use (e.g. for biological decomposition) \\
\hline & Harmful emissions & High volume of harmful emissions ( $\mathrm{CO}_{2}$ and other) \\
\hline & Impacts on worker's health & Safe production \\
\hline \multirow{2}{*}{ Transport } & \multirow{2}{*}{$\begin{array}{l}\text { Distance and energy } \\
\text { consumption }\end{array}$} & Low distances/ locally available materials \\
\hline & & Effective methods of transport \\
\hline \multirow{5}{*}{ Installation } & Energy consumption & $\begin{array}{l}\text { Minimum in energy consumption/ Energy from } \\
\text { renewable resources }\end{array}$ \\
\hline & Water consumption & Low water consumption \\
\hline & Solid waste production & Minimum solid and liquid waste generation \\
\hline & Noise and dust production & Minimum noise and dust generation \\
\hline & Impacts on worker's health & Safe production \\
\hline \multirow{2}{*}{$\begin{array}{l}\text { Use and } \\
\text { maintenance }\end{array}$} & Durability & Long-lasting \\
\hline & Maintenance & Easy to maintain/ Low energy/water consumption \\
\hline \multirow{2}{*}{$\begin{array}{l}\text { Use and } \\
\text { maintenance }\end{array}$} & Impacts on user's health & $\begin{array}{l}\text { Materials without harmful substances/ Low emissions/ } \\
\text { Absence of radon }\end{array}$ \\
\hline & $\begin{array}{l}\text { Impacts on outdoor } \\
\text { environment }\end{array}$ & Materials with optimal thermal performance \\
\hline \multirow{5}{*}{ Decomissioning } & Energy consumption & $\begin{array}{l}\text { Minimum in energy consumption/ Energy from } \\
\text { renewable resources }\end{array}$ \\
\hline & Water consumption & Low water consumption \\
\hline & Solid waste production & Minimum solid and liquid waste generation \\
\hline & Noise and dust production & Minimum noise and dust generation \\
\hline & Influence on worker's health & Safe production \\
\hline Reuse & Possibility of reuse & Material either may be reused or is reused \\
\hline Recycling & Possibility of recycling & Material either may be recycled or is recycled \\
\hline Disposal & Possibility of biodegradation & Material with possible biological decomposition \\
\hline
\end{tabular}


Table 4. Construction technologies applied in sustainable construction discussed in lectures course based on [15-21]

\begin{tabular}{|c|c|c|}
\hline $\begin{array}{l}\text { Basic technologies in } \\
\text { sustainable } \\
\text { construction }\end{array}$ & $\begin{array}{l}\text { Examples of materials and } \\
\text { products applied }\end{array}$ & Construction technique \\
\hline \multirow{3}{*}{$\begin{array}{l}\text { Natural local materials } \\
\text { and composites }\end{array}$} & $\begin{array}{l}\text { Timber, straw and other vegetable } \\
\text { products }\end{array}$ & $\begin{array}{l}\text { Traditional techniques with dominations } \\
\text { of hand work (framed, masonry) }\end{array}$ \\
\hline & $\begin{array}{l}\text { Earth: rammed earth, earth blocks } \\
\text { earth bags (superadobe) }\end{array}$ & Masonry, monolithic \\
\hline & Composites (hempcrete) & Monolithic, masonry \\
\hline \multirow[t]{2}{*}{ Reused products } & $\begin{array}{l}\text { Structural elements and products made } \\
\text { of durable materials like steel (steel } \\
\text { framework, ship containers), reinforced } \\
\text { concrete (concrete panels, tube } \\
\text { elements etc.) }\end{array}$ & $\begin{array}{l}\text { Block-container (metal) } \\
\text { frame-panel building (metal) } \\
\text { Spatial blocks (concrete) } \\
\text { Monolithic (panel formwork) }\end{array}$ \\
\hline & Masonry units with recycled content & Masonry \\
\hline Recycled products & $\begin{array}{l}\text { Masonry units made of construction and } \\
\text { urban wastes }\end{array}$ & Masonry \\
\hline \multirow{2}{*}{$\begin{array}{l}\text { Advanced materials } \\
\text { and technologies }\end{array}$} & Cellular clay block system & $\begin{array}{l}\text { Masonry walls } \\
\text { precast construction (clamping ceiling) }\end{array}$ \\
\hline & HCH system (block containing perlite) & Masonry walls \\
\hline \multirow{2}{*}{$\begin{array}{l}\text { Smart materials and } \\
\text { technologies }\end{array}$} & Smart glazing & $\begin{array}{l}\text { Windows and façade glazing in the } \\
\text { building of different structural systems }\end{array}$ \\
\hline & Photovoltaic power systems & $\begin{array}{l}\text { Panels for coating the roofs and facades } \\
\text { of different structural systems }\end{array}$ \\
\hline
\end{tabular}

\section{Course project}

The content of lectures permits student to select of energy-efficient ecological building materials for basic structural elements of assigned building, to determine thermal and energy parameters of basic structural elements; to select sustainable technological methods for construction.

When given foot-plans and cross sections of model residential buildings (single-family and multiple dwelling) and region of construction, students are assigned to select type of construction technique and designing basic structural assemblies of the building: basements, walls and roof applying thermal insulation materials known from lectures. According to assignment in terms of energy efficiency the student has to calculate required thermal parameters of the assemblies and energy parameters: embodied energy for the assembly and specific heating energy of a building. The data for calculation can be obtained from the lecture notes as well as from open source database and technical specifications of the manufacturers.

During studying the subjects, student is able to familiarize with open online tools for LCA of buildings depending on selected building materials (like Athena Institute software). According to the assignment student calculates the basic LCA parameters of residential or commercial building knowing total footage of the basic structural assemblies and the region of construction [22]. Within the work on the project student compare different variants and analyze the information obtained from calculations to make rational selection. 


\section{Conclusions}

The subjects "Building Materials in Energy-efficient Construction" and "Technologies in Sustainable Construction", developed as a part of Civil Engineering Master Studies curricula „Building ecological Europe” offer rather wide range of discussed issues. The rational selection of the materials and technologies for energy-efficient sustainable construction is of great importance at modern construction process and depends on many factors at all the stages of material and building life cycle. As energy efficiency and sustainability become the key aspects of civil engineering development, the main issues of the subjects are vital in teaching of civil engineers in "Building and Engineering Structures".

At the end of the studying the subjects, student will have knowledge of the energy efficiency criteria of building materials, on the types and properties of building materials for energy-efficient construction. Student will be able to select rationally building materials for energy-efficient construction. Student will understand possible uses of different methods and tools for estimating the energy efficiency of buildings and critically evaluate the results of calculations.

He will have knowledge of the principles and criteria of sustainable construction, basic technologies and basic materials used in sustainable construction. Student is supposed to select building materials for sustainable construction and understand possible uses of different methods and tools, including computer programs for estimating the construction's influence on the environment. The student will be able to evaluate critically the results of calculations.

\section{Acknowledgement}

The paper was prepared on the basis of the subjects' materials developed under supervision of Professor of Lublin University of Technology Dr. Eng. Stanislaw Fic in coauthorship with M Sc Eng. Małgorzata Szafraniec.

\section{References}

1. Hall M. (Ed.) Materials for energy efficiency and thermal comfort in buildings. 1st ed. Elsevier Science; Woodhead Publishing, 2010.

2. Hoseini A.H.G., Dahlan N.D., Berardi U., Hoseini A.G., Makaremia N., Hoseini M.G. Sustainable energy performances of green buildings: A review of current theories, implementations and challenges. Renewable and Sustainable Energy Reviews 25 (2013) 1-17.

3. Katedra Inżynierii Materiałów Budowlanych. [online] Available at: http://wbia.po.opole.pl/?acc=katedra_imb [Accessed 10 March 2016].

4. Ecological technologies in building industry $B B / K / Z-Z U>T E w B$. The syllabus. [online] Available at: https://ects.prz.edu.pl/en/courses/view?prz_kod=BB/K/Z-ZU\%3ETEwB [Accessed 11 March 2016].

5. Wydział Inżynierii Lądowej. Politechnika Warszawska. Studia II Stopnia (Magisterskie). [online] Available at: https://www.il.pw.edu.pl/index.php/pl/studia/ii-stopnia-magisterskie [Accessed 11 March 2016].

6. Wydział Budownictwa i Architektury. Budownictwo. Studia stacjonarne (dzienne) I stopnia. [online] Available at: http://www.wbia.zut.edu.pl/wbia/o-wydziale/kierunki-i-rodzajestudiow/budownictwo.html [Accessed 10 March 2016]. 
7. Energy Saving Construction. About study program. [online] Available at:

https://usosweb.uwm.edu.pl/kontroler.php?_action=katalog2\%2Fprogramy\%2FpokazProgram

\&prg_kod=1105-SI-BE\&lang=en [Accessed 13 March 2016].

8. Sustainable Building Technology MSc. [online] Available at:

https://www.nottingham.ac.uk/pgstudy/courses/architecture-and-built-environment/sustainablebuilding-technology-msc.aspx [Accessed 28 February 2016].

9. Energy-efficient and Environmental Building Design - Master's Programme. [online] Available at: http://www.lunduniversity.lu.se/lubas/i-uoh-lu-TAEMB [Accessed 1 March 2016].

10. Berge B. The ecology of building materials. 2nd ed. Oxford, Elsevier - Architectural Press, 2009, (239-252).

11. Yarbrough D.W. Specifying reflective insulation: applications for the building envelope and equipment use. Construction Canada, March (2014) 76-82. [online] Available from: http://www.kenilworth.com/publications/cc/de/201403/files/76.html [Accessed 28 February 2016].

12. Jovanović-Popović M., Kosanović S. Selection of building materials based upon ecological characteristics: priorities in function of environmental protection, Spatium, International Review 20 (2009) 23-27.

13. El Khouli S., John V., Zeumer M. Sustainable Construction Techniques. Detail Green, 2015, $152 \mathrm{p}$.

14. Pulaski M.H. (Ed.) The field guide for sustainable construction, Design-Build Institute of America, 2004, 312p.

15. Elsayed M. Straw Bale is Future House Building Material. Egypt, 2000.

16. Flatau R., Cordwood construction: best practices: A log home building method using renewable resources and time honored techniques: 1. Cordwood construction resources, 2012.

17. Green Roof Handbook Conservation Technology, Inc. 10/08. [online] Available at: http://www.conservationtechnology.com/documents/GreenRoofHandbook1008.pdf. [Accessed 27 February 2016]

18. Hradil P. et al. Re-use of structural elements. Environmentally efficient recovery of building components. VTT Technology 200, 2014. [online] Available at:

http://www.vtt.fi/inf/pdf/technology/2014/T200.pdf. [Accessed 27 February 2016]

19. HCH system. HCH catalog. 2013.

20. Hunter K., Kiffmeyer D. Earthbag building. The tools, tricks and techniques. New Society Publishers, 2004.

21. Rael R. Earth architecture. 2008, New York, Princeton Architectural Press, 208 p.

22. Athena. EcoCalculator for residential and commercial assemblies. [online] Available at: http://www.athenasmi.org/our-software-data/ecocalculator/ [Accessed 25 February 2016] 